\title{
OPTIMALISASI PELAYANAN DI UPT PERPUSTAKAAN UNIVERSITAS MUHAMMADIYAH MATARAM
}

\author{
OPTIMIING SERVICES IN LIBRARY OF MUHAMMADIYAH MATARAM UNIVERSITY
}

\author{
Abdul Munawir ${ }^{1}$, Iskandar ${ }^{2}$, Iwin Ardyawin ${ }^{3}$ \\ 1.2,3) Universitas Muhammadiyah Mataram \\ ${ }^{2}$ Email: iskandarngali94@gmail.com \\ 3Email: iwinardyawin@gmail.com
}

\begin{abstract}
ABSTRAK/ ABSTRACT
Perpustakaan perguruan tinggi sebagai salah satu sumber ilmu pengetahuan yang memiliki peran besar bagi kebutuhan penggunanya khususnya mahasiswa untuk menyelesaikan studinya di suatu perguruan tinggi. Oleh karena itu, perpustakaan pada suatu perguruan tinggi mempunyai fungsi sebagai sumber pendidikan yang menyangkut fungsi edukasi, fungsi informasi, fungsi riset, fungsi, fungsi rekreasi, fungsi publikasi, artinya perpustakaan perguruan tinggi merupakan salah satu sarana informasi yang memiliki fungsi sebagai jembatan ilmu bagi seluruh komponen masyarakat perguruan tinggi terutama bagi mahasiswa yang sedang dalam proses menyelesaikan studinya. Sehingga perlu adanya pengoptimalan kegiatan pelayyanan perpustakaan pada UPT Perpustakaan Univeristas Muhammadiyah Mataram. Metode yang digunakan dalam penelitian ini dengan cara terjun lamgsung dalam melakukan pengoptimalan pelayanan perpustakaan di UPT Perpustakaan Universitas Muhammadiah Mataram. Hasil dari pengabdian ini adalah pengoptimalan kegiatan pelayanan dalam bidang teknis agar kemudahan dalam temu Kembali informasi dan pengoptimalan layanan informasi kepada sulurh mahasiswa Univeristas Muhammadiyah Mataram.
\end{abstract}

Kata Kunci : Pelayanan, perpustakaan, mahasiswa

Submited : 29 Oktober 2021

Revision :02 November 2021

Accepted : 05 November 2021

\section{A. PENDAHULUAN}

Dalam rangka mencerdaskan kehidupan bangsa sebagaimana diamanatkan dalam Undang Undang Dasar Negara Republik Indonesia Tahun 1945, perpustakaan sebagai wahana belajar sepanjang hayat mengembangkan potensi masyarakat agar menjadi manusia yang beriman dan bertakwa kepada Tuhan Yang Maha Esa, berakhlak mulia, sehat, berilmu, cakap, kreatif, mandiri, dan menjadi warga negara yang demokratis serta bertanggung jawab dalam mendukung penyelenggaraan pendidikan nasional

Perpustakaan adalah institusi pengelola koleksi karya tulis, karya cetak, dan/atau karya rekam secara profesional dengan sistem yang baku guna memenuhi 
kebutuhan pendidikan, penelitian, pelestarian, informasi, dan rekreasi para pemustaka (Undang-undang RI. Nomor 43 Tahun 2007 Tentang Perpustakaan). Hal ini sejalan dengan upaya untuk memelihara dan meningkatkan efesiensi dan efektifitas proses belajar mengajar dan dapat memberikan kemudahan dalam proses belajar dan mengajar tentunya dengam fasilitas yang memadai, merujuk dari sudut pandang tersebut maka pengadaan perpustakaan di lembaga pendiudikan termasuk perpustakaan perguruan tinggi merupakan suatu keharusan.

Menurut Sudibyo (1987) perpustakaan perguruan tinggi yaitu suatu unit kerja yang merupakan bagian integral dari suatu lembaga induknya bertugas dalam membantu perguruan tinggi melaksanakan Tridarma, selaras dengan pendapat tersebut, Sulistiyo Basuki juga berpendapat bahwa perpustakaan perguruan tinggi adalah perpustakaan yang terdapat pada perguruan tinggi, badan bawahannya, maupun lembaga yang berafiliasi dengan perguruan timggi, dengan tujuan utama membantu perguruan tinggi (pendidikan, penelitian, dan pengabdian masyarakat)

Dari kedua pendapat di atas dapat di tarik kesimpulan bahwa yang dimaksud perpustakaan perguruan tinggi adalah perpustakaan yang terdapat pada perguruan tinggi yang memiliki fungsi menyediakan dan mendistribusikan informasi khususnya dalam lingkup perguruan tinggi guna membantu perguruan tinggi tersebut dalam mencapai tujuannya yakni Tri Dharma perguruan tinggi, untuk dapat tercapainya tujuan tersebut maka perpustakaan perguruan tinggi harus menjalankan fungsinya dengan baik, fungsi utama perpustakaan perguruan tinggi dapat ditinjau dari beberapa aspek, sebagaimana yang di kemukakan oleh Noerhayati Sudibyo bahawa terdapat dua fungsi perpustakaan yaitu, 1) Ditinjaua dari proses pelayanannya berfungsi sebagai pusat informasi,pusat pelestarian informasi, pusat pengelolaan informasi, pusat pemanfaatan informasi, dan pusat penyebarluasan informasi. 2) Ditinjau dari program kegiatan perguruan tinggi memiliki fungsi sebagai pusat layanan informasi untuk: program pendidikan, penelitian dan pengabdian masyarakat.

Dalam lingkungan Perguruan Tinggi perpustakaan dianggap sebagai jantungnya Universitas, hal ini dikarenakan perpustakaan perguruan tinggi berperan sebagai penunjang dalam kegiatan pendidikan, penelitian dan pengabdian pada 
masyarakat, maka dari itu pemerintah melalaui UU No.43 Tahun 2007 Tentang Perpustakaan, Bagian Ke Empat Pasal 24, mangatur:

Setiap Perguruan Tinggi menyelenggarakan perpustakaan yang memenuhi standar Nasional Perpustakaan dengan memperhatikan Standar Nasional Pendidikan, baik dalam jumlah judul, jumlah eksemplar yang mencakupi untuk mendukung pelaksnaan, pendidikan, penelitian, dan pengabdian pada masyarakat, sehubungan dengan hal itu setiap Perguruan Tinggi mengalokasikan dana untuk pembangunan perpustakaan sesuai dengan peraturan dan perundang-undangan guna memenuhi standar nasional pendidikan dan juga standar nasional perpustakaan

Perpustakaan perguruan tinggi sebagai salah satu sumber ilmu pengetahuan yang memiliki peran besar bagi kebutuhan penggunanya khususnya mahasiswa untuk menyelesaikan studinya di suatu perguruan tinggi. Oleh karena itu, perpustakaan pada suatu perguruan tinggi mempunyai fungsi sebagai sumber pendidikan yang menyangkut fungsi edukasi, fungsi informasi, fungsi riset, fungsi, fungsi rekreasi, fungsi publikasi, artinya perpustakaan perguruan tinggi merupakan salah satu sarana informasi yang memiliki fungsi sebagai jembatan ilmu bagi seluruh komponen masyarakat perguruan tinggi terutama bagi mahasiswa yang sedang dalam proses menyelesaikan studinya

\section{B. METODE}

Pelaksanaan kegiatan ini dilaksanakan di UPT Perpustakaan Universitas Muhammadiyah Mataram. Waktu pelaksanaan mulai tanggal 16 Maret 2021 hingga 30 April 2021 atau selama 1,5 bulan. Metode yang digunakan dalam melakukan kegiatan ini dengan terjun langsung terlibat dalam kegiatan pelayanan di UPT Perpustakaan Universitas Muhammadiyah Mataram.

\section{HASIL DAN PEMBAHASAN}

Sistem layanan yang digunakan oleh UPT. Perpustakaan Universitas Muhammadiyah Mataram adalah sistem pelayanan terbuka, dimana pemustaka atau pengguna bebas mengambil koleksi yang diinginkan.sistem layanan sirkulasi di UPT. Perpustakaan Universitas Muhammadiyah Mataram yaitu sistem otomasi dengan menggunakan SLiMS Akasia dan SLiMS Cendana. 
UPT Perpustakaan Muhammadiyah Mataram saat ini memiliki total koleksi umum pada tahun 2021 sejumlah 9.330 judul dengan 17.293 eksemplar, koleksi yang sedang dipinjam sebanyak 427 dan 16.866 total eksemplar tersedia yang dapat dimanfaatkan oleh para pemustaka.

Salah satu kegiatan rutin yang kami lakukan adalah pengolahan bahan pustaka, yaitu suatu kegiatan yang dilakukan dari bahan pustaka perpustakaan mulai masuk sampai dengan siap untuk di manfaatkan atau di pinjam oleh pemustaka. Kegiatan yang rutin dilakukan antara lain:

\section{Kegiatan di Perpustakaan}

Pengolahan bahan pustaka merupakan kegiatan yang berkaitan dengan bahan pustaka yang mulai dari buku tiba di perpustakaan hingga bisa di pinjam oleh pemustaka. Pengolahan kami lakukan dari bulan Maret hingga bulan April, namun kami tidak melakukannya setiap hari, melainkan selang- seling dengan kegiatan yang berbeda beda.

Terdapat buku pedoman klasifikasi yang digunakan oleh UPT. Perpustakaan Muhammadiyah Mataram adalah Dewey Decimal Classificationoleh Drs. Towa P. Hamakonda, MLs. J.N.B. Tairas dan Terjemahan Klasifikasi Desimal Dewey Edisi ke-14 yang di terbitkan oleh Perpustakaan Nasional RI. Adapun proses pengolahan yang dilakukan sebagai berikut:

a. Inventaris

Inventaris adalah kegiatan mencatat setiap eksamplar buku dalam buku induk dan memberi nomer induk atau untuk setiap eksamplar buku kemudian mencatat dalam buku inventaris (Soetminah, 1992: 81).

Kegiatan inventaris adalah memeriksa, memberi stempel, dan mencatat atau mendaftar semua koleksi perpustakaan dalam buku induk dan diberi nomer induk tersendiri, seperti buku induk untuk koleksi buku, majalah, surat kabar, dan lain sebagainya.

Manfaat Inventaris adalah memudahan pustakwan dalam merencanakan pengadaan koleksi pada tahun-tahun berikutnya dan memudahkan pustakawan melakukan pengawasan terhadap koleksi yang dimilikinya.

Unsur-unsur yang ada dalam buku inventaris atau yang semuala dikenal dengan nama buku induk adalah tanggal, bulan, dan tahun pencatatan, nomer 
induk buku (setiap satu eksamplar diberi nomer yang berbeda), judul buku, nama pengarang, edisi, penerbit, tahun terbit, tempat terbit, Bahasa, asal buku (beli, hadiah, proyek, tukar-menukar, dan lainnya), jenis buku, dan keterangan. Hal-hal tersebut bisa titulis dengan manual atau bisa juga masuk dalam database.

Inventaris adalah pencatatan bahan pustaka baik yang di dapat dari pembelian, hadiah, maupun tukar menukar ke dalam buku induk. Tujuan inventaris buku dalam kegiatan mencatat buku induk UPT. Perpustakaan Muhammadiyah Mataram sebagai berikut:

1) Judul Buku

2) Nama Pengarang

3) Penerbit

4) Kota terbit

5) Tahun terbit

6) Jumlah eksemplar

7) Sumber buku (pembelian, hadiah, atau sumbangan)

Pembagian sumber buku di UPT. Perpustakaan Muhammadiyah Mataram menggunakan kode PB untuk pembelian, HD untuk hadiah, dan SB untuk sumbangan.

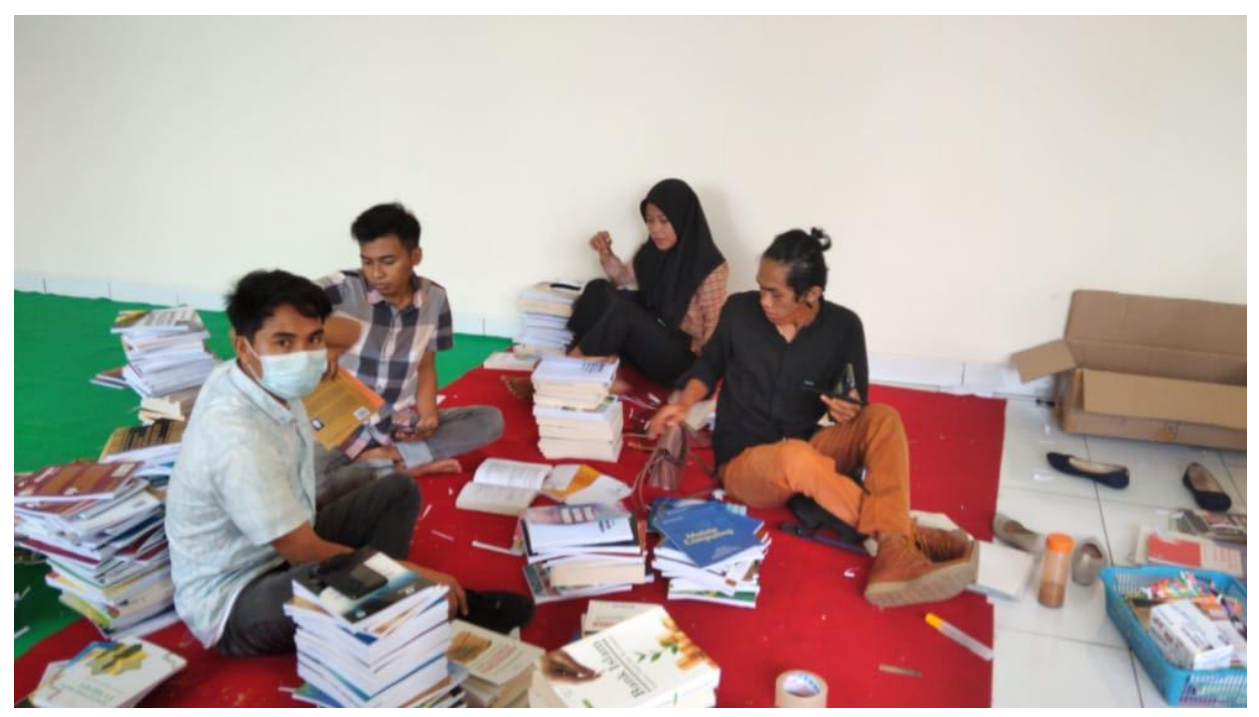


b. Pemberian Stempel Perpustakaan Muhammadiyah Mataram

Pemberian stempel perpustakaan bertujuan untuk memberikan identitas tentang koleksi bahan pustaka yang memiliki badan atau instansi. Dalam pemberian stempel ini terdiri dari stempel hak milik sesuai dengan standar perpustakaan.

Adapun tata cara dalam pemberian stempel pada bahan pustaka yaitu:

1) Di halaman depan.

2) Di halaman tengah.

3) Halaman terakhir

Terdapat juga stempel rahasia yang terdapat pada halaman 5 dan halam 11 dengan ketentuan stempel tidak mengganggu dan meghalagi teks buku. Dari hasil pengamatan penulis, koleksi-koleksi yang ada pada umumnya sudah dilakukan pemberian stempel sesuai dengan ketentuan yang berlaku seperti yang diuraikan di atas.

c. Klasifikasi

Klasifikasi adalah kegiatan memilih, menyusunan dan mengelompokkan secara sistematis berdasarkan subjek buku atau benda-benda lain ke dalam kelas atau golongan tertentu berdasarkan ciri-ciri dan yang sama (Hamakonda, 2014:31).Fungsi klasifikasi adalah sebagai alat penyusun koleksi di rak, dan sebagai sarana penyusun entri bibliografi dalam katalog tercetak, bibliografi dan indeks dalam tata susunan sistematis. yaitu:

1) Pengelompokan atau klasifikasi arikel yang artinya sistem pengelompokan koleksi berdasarkan ukuran, warna, atau data fisik lainnya.

2) Pengelompokan klasifikasi fundamental artinya pengelompokan berdasarkan subyek tertentu.

Adapun tujuan adanya klasifikasi yaitu dapat menentukan koleksi bahan pustaka di dalam jajaran koleksi perpustakaan agar memudahkan dan mempersingkat waktu temu kembali informasi dan mengumpulkan semua bahan pustaka yang memiliki subyek yang sama dalam suatu jajaran koleksi. Sedangkan manfaat klasifikasi, yaitu untuk mengetahui bahan pustaka dan keseimbangan koleksi yang dimiliki perpustakaan dan untuk mengetahui cakupan ilmu pengetahuan. Sistem klasifikasi yang sering digunakan di 
perpustakaan adalah Dewey Decimal Classification (DCC), Universal Decimal Classification (UDC) dan Library of Congress Classification (LCC). Sistem klasifikasi ini mencakup semua bidang ilmu pengetahan yang dibagi menjadi sepuluh cabang dengan pecahan persepuluh.

d. Labeling atau pelabelan

Labeling adalah kegiatan pengolahan bahan pustaka yang memberikan perlengkapan buku untuk dapat membantu memberikan kemudahan dalam layanan perpustakaan ada beberapa pekerjaan labeling yang dapat dilakukan oleh perpustakaan yaitu:

1) memberi label

Penempelan label ini di tempatkan di punggung buku bagian bawah dengan ukuran $5 \times 6 \mathrm{~cm}$

2) menempel kantong buku

kantong buku biasanya ditempel dalam kulit buku belakang dan bahan yang dipakai biasanya kertas kesting karton manila.

3) memasukkan kartu buku ke kantong buku

kartu buku dimasukkan ke dalam kantong buku yang sudah di temple sebelumnya dengan ukuran lebih kecil dari ukuran kantong buku, yaitu 7x13 $\mathrm{cm}$, bahan yang biasanya di pakai adalah karton manila.

4) Menempel lembar slip pengembalian dan peminjaman ditempatkan pada halaman terakhir buku dan kartu buku yang telah di tempel di sampingnya, dengan ukuran 8x15 cm dengan bahan HVS.

5) Pemasukan data (data entry)

Pemasukan data (data entry) adalah kegiatan pengisian data bibliografi atau data buku secara lengkap ke dalam program aplikasi seperti Senayan Library Managemen Sistem (SLIMS) agar dapat dilayankan atau dipinjamkan kepada pemustaka yang membutuhkan bahan pustkaa tersebut. 
6) Penyelesaian fisik bahan pustaka

Kegiatan penyelesaian fisik bahan pustaka adalah kegiatan pembuatan kelengkapan fisik bahan pustaka perpustakaan. Adapun kelengkapan bahan pustaka yang harus dilengkapi yaitu, sebagai brikut:।

a) Label buku atau tanda buku (call number)

Label buku terdiri dari, nomer klasifikasi (nomor golongn ilmu atau subjek), tiga huruf pertama dari pengarang, dan satu huruf pertama dari judul buku. Unsur tersebut diketik diatas kertas secara berurutan dari atas ke bawah, selanjutnya ditempelakan pada punggung buku dengan jarak dan ukuran yang tentukan

b) Barcode

Barcode yaitu kode baris yang hanya bisa dibaca dengan barcode reader.Menurut pendapat (Lasa Hs, 2008: 9) barkode yaitu pembaca sandi palang.

c) Lembar tanggal Kembali

Lembar tanggal kembali adalah lembar yang ditempal pada halaman terakhir buku. Lembar ini berguna sebagai alat kontror bagi peminjam buku kerena berisi tentang tanggal kapan buku harus dikembalikan.

d) Shelving

Shelving adalah kegiatan penjajaran koleksi kedalam rak atau tempat koleksi berdasarkan system tertentu. kegiatan ini merupakan langkah terakhir dari proses pengolahan bahan pustaka. Tujuannya agar koleksi dapat ditemukan dengan mudah dan dapat dikenali oleh pengguna atau pustakawan.

Sistem penjajaran koleksi kedalam rak buku yaitu, sebagai berikut: Berdasarkan jenis, yaitu disusun berdasarkan jenis koleksi dalam bidang apapun dijadikan satu susunan. Sistem ini cocok untuk penjajaran koleksi referensi.

Berdasarkan sandi pustaka atau call number, yaitu disusun berdasarkan nomer kelas buku sesuai dengan tata susunan koleksi, sistem ini cocok untuk penjajaran koleksi buku teks. 
Dalam penjajaran buku ini perlu diperhatikan hal-hal berikut:

Rak tidak diisi penuh untuk memudahkan penambahan dan pengeseran buku

Menggunakan standar buku

Buku tidak disusun berlapis atau menumpuh

Rak hendaknya mudah dipindahkan

Desain rak hendaknya disesuaikan agar sirkulasi udara baik.

\section{Layanan Perpustakaan}

Adapun Jenis-jenis layanan perpustakaan antara lain:

a. Layanan pembuatan akun repository

Layanan repository secara sederhana adalah tempat penyimpanan suatu informasi, dalam kepustakawanan repository adalah suatu tempat dimana dokumen, imformasi atau data simpan, kegiatan ini merupakan penghimpunan dan melestarikan koleksi dalam bentuk digital yang merupakan karya ilmiah hasil dari inelektual atau pemikiran suatu individu seperti skripsi, tesis, laporan penelitian, laporan PKL.

Penulis dapat meng-upload mandari karya ilmiahnya dengan terlebih dahulu membuat akun repository, sebelum membuat akun repository penulis di haruskan memberikan lembar plagiasinya ke admin, kemudia admin menginput NIM, nama, program studi, alamat, alamat email, dan nomer telepon yang terdapat pada lembar plagiasi, kemudian admin mengarahkan tata cara penyusunan mulai dari logo, watermark, lampiran hingga tata cara mengupload karya ilmiah dari penulis tersebut, dengan cara terlebih dahulu login menggunakan username dan password yang di berikan oleh admin dengan cara mengakses halaman https://repository.ummat.ac.id terlebih dahulu.

b. Layanan Sirkulasi

Salah satu tolak ukur keberhasilan suatu perpustakaan dapat dilihat dari seberapa optimal layanan sirkulasi dapat memenuhi kebutuhan pemustaka. Layanan sirkulasi merupakan kegiatan layanan yang menangani kegiatan mulai dari peminjaman, pengembalian, pendaftaran keanggotaan perpustakaan, menentukan denda hingga membuat peraturan dalam hal pemakaian dan 
peminjaman bahan pustaka, seperti jangka waktu peminjaman, jumlah koleksi yang dapat di pinjam per orang, siapa saja yang dapat meminjam koleksi, dan syarat-syarat peminjaman koleksi perpustakaan dengan maksud untuk meningkatkan keterpakaian koleksi-koleksi perpustakaan secara optimal.

Adapun kegiatan-kegiatan layanan sirkulasi antara lain sebagai berikut:

1) Mengarahkan pemgunjung untuk mengisi daftar kunjungan yang telah di sediakan

2) Mengontrol tempat penitipan barang pemustaka

3) Mengawasi koleksi yang keluar dari perpustakaan.

4) Mengurus pendaftaran anggota baru, perpanjangan keanggotaan, dan mengurus pengunduran diri keanggotaan dengan syarat memiliki surat bebas pinjam.

5) Mengurus mulai dari peminjaman, pengembalian, hingga perpanjangan peminjaman koleksi perpustakaan

6) Memperingatkan peminjam yang terlambat mengembalikan koleksi perpustakaan melalui telepon maupun secara langsung.

7) Menentukan denda apabila ditemukan peminjam yang terlambat mengembalikan koleksi dari waktu yang sudah di tetapakan

8) Mencatat pesanan peminjaman anggota lain yang bermaksud meminjam bahan pustaka yang masih dalam status pinjam.

9) Mengontrol kelayakan koleksi, apabila di temukan kerusakan sebaiknya koleksi di arahkan ke bagian restorasi dan apabila kerusakan tersebut disebabkan oleh peminjam maka peminjam harus diperingatkan, dan memungkinkan peminjam harus mengganti koleksi yang rusak maupun hilang dengan judul yang sama.

10) Bertanggung jawab atas berkas peminjaman, seperti catatan peminjaman, berkas anggota, catatan penerimaan uang denda, penggantian buku yang hilang, dan daftar pengunjung.

11) Mengembalikan koleksi yang telah selesai digunakan, baik dipinjam atau dibaca ditempat ke rak koleksi sesuai dengan nomor klasifikasinya (pergerakan/shelving). 
12) Membuat statistik keterpakaian koleksi (koleksi dibaca, dipinjam, dan difotokopi) dan statistik pengunjung.

Selain kegiatan diatas, kegiatan layanan sirkulasi sebagai berikut:

1) Layanan Pembuatan Kartu Anggota

Layanan pembuatan kartu anggota merupakan layanan yang diberikan pustakawan kepada pemustaka yang ingin menjadi anggota perpustakaan. Layanan pembuatan kartu anggota bertujuan untuk memudahkan pemusta yang ingin memanfaatkan perpustakaan. Setelah membuat kartu anggota perpustakaan, pemustaka dikenakan biaya administrasi anggota perpustakaan sebesar Rp.10.000.

2) Layanan Perpanjang Kartu Anggota

Layanan ini diberikan dengan tujuan untuk memudahkan pemustaka yang ingin memperpanjang masa keanggotaan perpustakaan yang telah berakhir. Pemustaka yang telah memperpanjang masa keanggotaan akan dikenakan biaya administrasi sebesar Rp. 5.000.

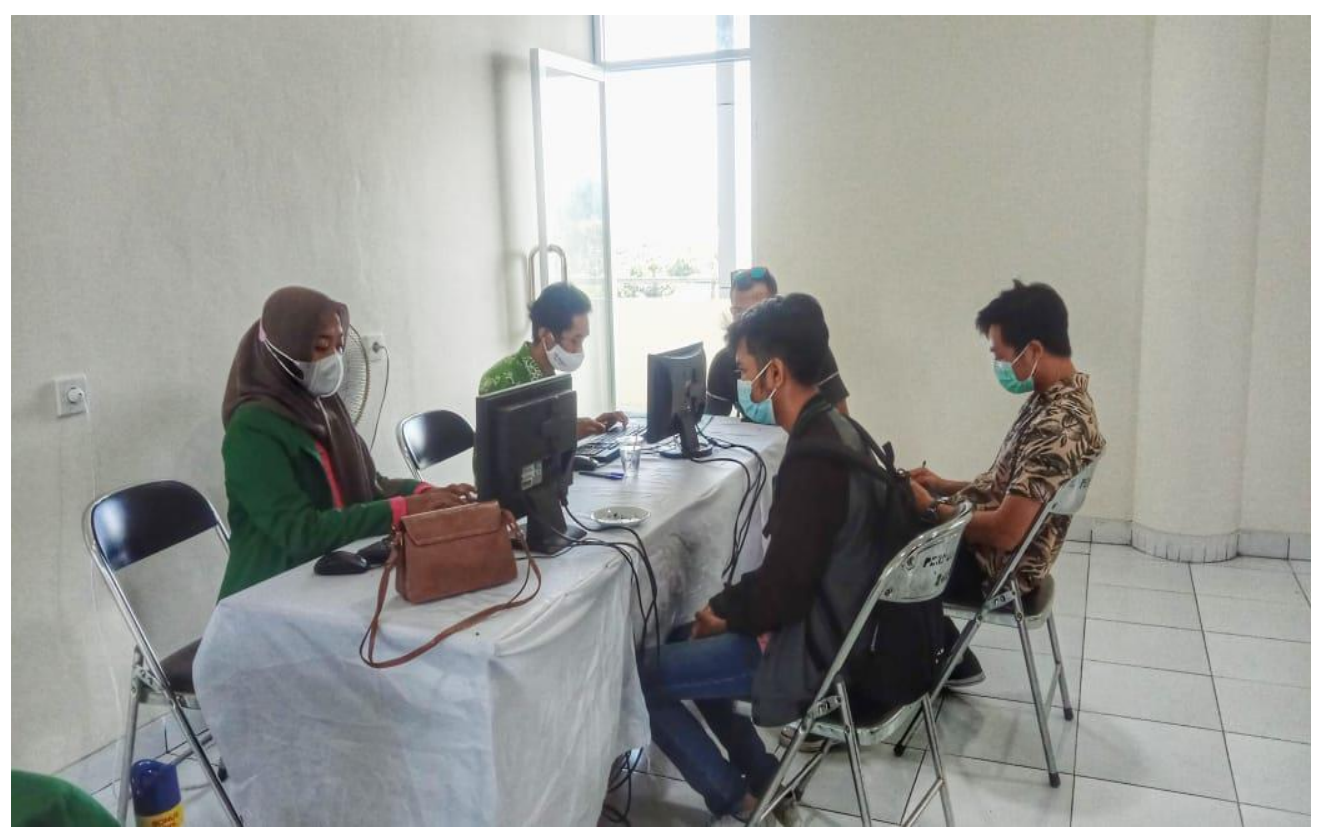

3) Layanan Referensi

Layanan referensi merupakan layanan yang berkaitan dengan bantuan yang diberikan pustakawan secara langsung kepada pemustaka dalam mencari informasi dan memanfaatkan perpustakaan secara efektif. 
Tujuan dari layanan referensi adalah membimbing pemustaka untuk memilih sumber rujukan yang tepat dalam menjawab pertanyaan pada subjek/bidang tertentu. Kegiatan layanan referensi terdiri dari 2 layanan, yaitu layanan tidak langsung dan layanan langsung. Layanan tidak langsung adalah layanan secara tidak langsung untuk membantu pemustaka dalam mengakses sejumlah informasi, seperti membuat bibliografi, indeks, dan layanan informasi perpustakaan melalui kerja sama antar perpustakaan. Sedangkan layanan langsung adalah layanan referens yang dilakukan secara langsung kepada pemustaka.

Layanan di UPT. Perpustakaan Muhammadiyah Mataram menggunakan layanan tidak langsung, yaitu pustakawan menyediakan bahan pustaka dan mengarahkan pemustaka untuk mencari informasi melalui perpustakaan digital dengan menggunakan aplikasi software yaitu Online Public Access Catalog (OPAC).

4) Layanan Akses Internet

Layanan akses internet merupakan layanan yang menyediakan akses penelusuran informasi supaya memudahkan pemustaka dalam mendapatkan informasi apa saja, baik yang berupa ilmiah maupun bersifat hiburan. Layanan akses internet yang di sediakan oleh UPT. Perpustakaan Muhammadiyah Mataram menyediakan layanan akses internet berupa wifi gratis kepada pemustaka agar dapat mengakses informasi yang dibutuhkan oleh pemustaka. 


\section{SIMPULAN}

Pelayanan Perpustakaan di Dinas Perpustakaan dan Kearsipan Kabupaten Lombok Timur sudah baik karena mampu memanfaatkan teknologi informasi yang dapat beriintegrasi dalam penyediaan informasi. Dinas Perpustakaan dan Kearsipan Kabupaten Lombok Timur menggunakan aplikasi Inlislite Versi 3.2, dengan adanya system aplikasi berbasis Integrated Library System ini dapat memudahkan pemustaka dalam temu kembali informasi dan pustakawan dalam mengolah bahan pustaka. Terutama adanya minat baca masyarakat sangat tinggi. Dilihat dari jumlah pengunjung dari berbagai kalangan yng sangat banyak dan dari kegiatan layanan perpustakaan keliling yang sangat diminati siswa-siswi sehingga perlunya peran pustskawan dalam menemukan informasi dan pendidikan pemakai dalam memanfaatkan secara maksimal perpustakaan. Dalam kegiatan pengadaan koleksi juga perlu memperhatikan kebutuhan informasi pemustaka sehingga kebutuhan informasi terpenuhi. Namun, terdapat beberapa kekurangan dalam hal penyediaan sarana ruang baca koleksi umum yang belum memadai sehingga diperlukan adanya pengembangan perpustakaan 


\section{DAFTAR PUSTAKA}

Hamakonda, Towa P., (2014). Pengantar Klasifikasi Persepuluhan Dewey. Jakarta: Gunung Mulia

Lasa HS. ((2008). Manajemen Perpustakaan. Jakarta: Gama Media.

Soedibyo, Noerhayati. (1987). Pengelolaan Perpustakaan, Bandung: Alumni

Undang-undang No. 43 Tahun 2007 Tentang Perpustakan. Jakarta: Perpustakaan Nasional RI. 2007. 